DOI: $10.20472 / S S .2017 .6 .2 .005$

\title{
CORRELATES OF COLORISM: FREEDOM OF SPEECH AND DISCRIMINATORY ADVERTISING IN THAILAND
}

\author{
PAVEL SLUTSKIY, MARK HAMILTON
}

\begin{abstract}
:
In January 2016, the "Whiteness makes you win" advertisement of a skin-whitening product by Thai skincare company Seoul Secret went viral on Thai social media. The ad garnered international coverage from outlets such as CNN and the Guardian, with some local publications calling for legal action. The present study examines the legitimacy of this proposed legal initiative to outlaw "discriminatory advertising," drawing attention to the complex of intolerance and aggression that surrounds this topic. A content analysis of Thai media coverage of the Seoul Secret case was conducted. The sample of content included both print and online publications, including social media posts that mentioned the story. Results indicated that the value of free speech appears to be absent from the discourse about discriminatory advertising in Thailand.
\end{abstract}

\section{Keywords:}

Freedom of speech, discriminatory advertising, skin-whitening, racism

JEL Classification: M38

\section{Authors:}

PAVEL SLUTSKIY, Chulalongkorn University, Thailand, Email: pavel.slutsky@gmail.com MARK HAMILTON, University of Connecticut, United States, Email: mark.hamilton@uconn.edu

\section{Citation:}

PAVEL SLUTSKIY, MARK HAMILTON (2017). Correlates of Colorism: Freedom of Speech and Discriminatory Advertising in Thailand. International Journal of Social Sciences, Vol. VI(2), pp. 63-76., 10.20472/SS.2017.6.2.005 


\section{Introduction}

All across the planet, people spend considerable amounts of effort, time, and money in a quest to manipulate their skin tone in order to convey a message that elevates their social status. The vast majority of the world's cultures are characterized by colorism - a general preference for lighter complexions over darker complexions that extends to prejudice. In countries with a rural, agrarian past, consumers invest in whitening creams to communicate that they do not belong to the working class and are instead affluent. With prominent sectors of the economy that still entail outdoor manual labor, residents tend to privilege lighter skin. Colorism is both intensive and extensive in Asia and Africa, where it ranges from South to North, East to West. For example, 75\% of Nigerian women are reported to use them (United Nations Programme, 2008). Most major pharmaceutical conglomerates have a line of skin lighteners. They market their products with symbolic bluntness by choosing names such as The Spa Basic Skin Bleach, Daggett \& Ramsdell Skin Bleach, Loreal White Perfect, Namu Life Snail White Cream, and Black B' Gone.

Yet in countries with an urban, industrialized history, fair-skinned consumers invest in tanning creams and sprays to communicate that they have sufficient leisure time to develop a tan. This apparent anomaly underscores the capricious nature of colorism, where particular social groups set standards of preferred skin tone based on their own historical context. Colorism in Euro-American countries is convoluted. In countries with a history of enslaving and stigmatizing those with darker skin, colorism resembles what occurs across Asia. Although we can expect colorism and racism to co-vary, the correlation is less than perfect. Euro-American countries have many sectors of the economy that entail indoor service work so those with lighter complexions may privilege darker skin as an indicator of leisure time. In industrialized countries, colorism is therefore more moderate and scattered, tempered even more recently by concerns about the sun's harmful ultraviolet rays, and mixed with long struggles for civil rights. Despite the complexities of some Western cultures, the overall trend worldwide is toward colorism.

Products that lighten skin have raised two kinds of objection from society. First, many of the skin lightening products contain harmful chemicals such as mercury or steroids. As a consequence, several African countries have banned their use (Ivory Coast, The Gambia) while others exert strict control (South Africa). Second, campaigns in a number of countries have sought to discourage advertising for skin lightening products on the grounds that they promote discrimination against those with darker skin (Pakistan, Thailand). These movements range from criticism on social media (Kenya) to proposed legislation to ban such ads (Thailand). Thus, the products are alleged to cause both personal and social harm. After presenting a general model to explain the causes of colorism, the present study concentrates on the particular case of Thailand. 


\section{Colorism in Advertising}

In January 2016, the "Whiteness makes you win" advertisement promoting a skin-whitening product by Thai skincare company Seoul Secret went viral on Thai social media. The garnered international coverage from outlets such as CNN and the Guardian. Multiple publications mentioned that this is a clear-cut case of racial discrimination against specific ethnic communities, such as the 'Na Lao (Lao face) associated with the Thai Lao; the ad needs to be evaluated by the National Human Rights Commission as a priority.

One of the leading newspapers in Thailand - "The Nation" - in its editorial called for legal measures: "... Thailand must pass legislation to regulate the images and language of these adverts. This would help mobilise public opinion to challenge the socialisation processes which create the impression that Thai women are ugly or unsuccessful simply because of darker skin" (Draper, 09 Jan. 2016).

The online news publication Prachai also referred to the need of legislation: "It is also evident from the frequency of these 'whiteness' advert scandals that the skin-whitening industry in Thailand is out of control and needs to be reined in. The frequency also confirms a previous column suggesting racial discrimination and xenophobia are very real and worsening problems in Thailand.... If General Prayut is serious about implementing the 12 Thai core values regardless of race or color (a basic human value), for example by promoting the Philosophy of Sufficiency Economy as a bulwark against gross consumerism, he would be well advised to implement anti-racial discrimination quickly, as suggested by the CERD Committee during its meeting with the 2012 Thailand Country Delegation (CERD 2012a, b). This would help ensure that millions of Thai women presently socialized to believe that they are ugly will enjoy the protection of such core human rights legislation. The fact that such legislation does not exist in Thailand only confirms the severity of the existing problem". (Prachai 2016).

The present paper attempts to question the legitimacy of this proposed legal initiative to outlaw "discriminatory advertising", by drawing attention to the complex of intolerance and aggression that surrounds this topic.

\section{General Framework}

From the very beginning it needs to be clearly stated that this article does not intend to defend discrimination as a morally agreeable practice. Moreover, discriminatory advertising here is viewed as shameful and disgraceful form of promotion. However, while dealing with a social phenomenon that people do not like, they are confronted with a choice between two different options - one is legal/prosecutorial and the other is market driven through social/media pressure. The present paper clearly advocates the second and intends to make a case against the first. Whether discriminatory advertising is a criminal offence or a 
shameful practice that deserves sincere disapproval is an issue that deserves some thought.

It is probably true that the notion of beauty is socially constructed and its meanings are changed and maintained by social forces. The contemporary beauty discourse, dominated by celebrities, encourages individual empowerment through submission to skin color hierarchies. The rapid growth of communication technologies has disseminated images of white beauty, expanding the demand for products and procedures that can help build racial capital (Hunter 2011). Whitening skin is a social norm that "forces" women to follow such trends and standards as well as marketplace mythologies (Thompson 2004). Failure in following this norm will result in low self-esteem and social status. In social interaction contexts, white and fair skins are social symbols and regimes.

The desire for white and fair skin is a global phenomenon especially in non-white cultures and is not limited to Asian con- texts. African, South American and Middle-Eastern cultures also have their own traditions of skin whitening and lightening.

The "light at the top" phenomenon spread over non-white cultures. Those with light skin and Caucasian-looking features have also enjoyed more respect in their communities (Russell, Wilson, and Hall 1992). Euro-centric ideology took root in many cultures with the rise of colonialism in the eighteenth century and with the spread of mass media and consumer goods in the twentieth century. White males occupied the top of the social hierarchy while non-white females, especially black females, were at the bottom. People from non-white cultures, like African Americans, "bleached" themselves (first with folk preparations and later with commercial skin lighteners) in an attempt to blend in the dominant society (Hall 1995).

As Banton (1967) observes, race and ethnicity become the signs that lead to the assignment of positions in the overall system of exploitation. Mass media and marketers have aided and abetted this phenomenon by portraying distinctions between races and ethnic groups. Hollywood movies and mass media in the West frequently portray darker skin people as lower class, dirty, and evil, while white or light skin people are depicted as morally purer, better educated, more intelligent, and cleaner. Even Spike Lee's 1988 film School Daze emphasises this prejudice. Dark skin continues to be associated with unpleasantness, dirt, crime, and disruption of society (Russell, Wilson, and Hall 1992; Hall 1995) as well as lower social status, while light or white skin is associated with purity and higher social class. This social stratification process exists in non-western cultures as well. Dark skinned people in Japan are perceived as lower class (or farmers) since they work under the sun while light skinned people are more likely to have been sheltered indoors rather than working outside. 
According to Lipsitz (1998, p. 3), "the power of whiteness depended not only on white hegemony over separate racialized groups, but also on manipulating racial outsiders to fight against one another, to compete with each other for white approval, and to seek the rewards and privileges of whiteness for themselves at the expense-literally-of other racialized populations". Stereotypes among whites and non-whites spread from the intercultural arena to intra-cultural contexts. "Civilized White" and "Barbarous Black" (Russell 1996) ideologies became internalized in non-white cultures. Light and fair skin tone become the desired skin tone and was perceived as a "sign" of prestige within the non-white cultures on each continent.

\section{Thai Context}

Just like in many other non-white cultures "whiteness" is an important sign in presenting and constructing beauty in Thailand. Desire for "whiteness," under this chain of associations, is pursued for mixed reasons by women in everyday life. In the social context, white face and white skin can be identified as a form of performance (Goffman 1967, 1979), which presents and re-represents the beauty and virtue of an individual within the community.

Within the Thai context, while there are traditional sayings praising different colors of skin, only aphorisms praising whiteness - like "skin as radiantly light as the moon" - are well known. The abundance of skin-whitening products available in Thailand, and the efforts many Thai women go to shelter from the sun, highlights the obsession with pale skin. Darker skin is often associated in Thailand with manual, outdoor labour, and therefore with being "lower class".

Like in many countries across Southeast Asia, fairer skin is equated with higher class as it suggests a life not spent toiling in rice paddies under the sun. These days, rice farmers wear long sleeves, trousers, wide-brimmed hats and gloves. Also much of the urban elite are of ethnic Chinese origin, who tend to have lighter skin than the indigenous people of the Thai countryside. Since ancient times, Chinese poets have praised women with skin they compared to white jade or pearls. Skin-whitening products abound in Thailand, as they do all over Southeast Asia, with pale models advertising cosmetics, pills and diet supplements to lighten dark complexions. Using pale Korean and Japanese pop stars as illustrations, Thai women's magazines are full of fair-skinned Asians promoting products that promise to whiten, lighten and "boost" the complexion, with slogans such as "Show off your aura" and "Get to know the miracle of white skin". Fair-skinned actors and singers dominate the media nearly all over the Asia-Pacific region.

Products promise "the miracle of white skin" at the same time that common Thai insults use darker skin as a subject of denigration, like dam mhuen e-ga, "black like a crow". Thus critics of the whitening trend, such as Kultida Samabuddhi of the Bangkok Post, who wrote 
an opinion piece on the whitening feminine wash, say such products have changed the country's value system (Hodal 2013). But changing a value system and discrimination are two very different processes.

Although the degree to which skin-whitening products' advertisements are considered acceptable vary from country to country, these messages of white skin supremacy very rarely create positive responses either from the general public or academic community.

This seems to be a part of a world-wide movement in favor of outlawing racial discrimination in advertising as a form of hate speech, and this trend has had significant support in the past few years. As W. Block noted, "discrimination has been treated by large parts of the academic community as though it were not amenable to logical analysis, be it economic, ethical, or political; as though the very consideration of alternative viewpoints were somehow unsavory" (Block 2010, 117). But this holds true not only for academics -- political correctness has so spread throughout any discussion that criticisms of the mainstream view take on an aura of illegitimacy at the outset, even before arguments are heard in their behalf.

\section{Content Analysis}

While discussing a proposed law against discriminatory advertising we need to clearly understand that the proposed solution is to punish such advertisers by coercion and aggression, to intentionally cause them harm in response to their failure to advertise in a non-discriminatory manner. An attempt to prohibit discriminatory advertising aims to punish what we can refer to as peaceful speech. Any statement is a mere act of speech, communication, and as such it does not seem to include initiation of aggression or violence. That is why it is not an easy task to justify coercive measures as a legal punishment for non-violent actions.

The discourse about any legal proposal that intends to prohibit some forms of expression needs to be analyzed within the framework of the proposal and the value of free speech. Even if the idea of banning some forms of expression in business propaganda seems plausible, it is necessary to justify it argumentatively.

The problem should deserve further analysis in terms of what people often refer to as the conflict of values or conflicting rights. Properly understood, of course, this conflict cannot occur. If there is a seeming contradiction between rights, one of them is not really a right. But even if one does not agree with this assertion, then at least, before proposing such legislation or offering it for discussion in the public sphere it would be appropriate to assume that the right not to be discriminated against in advertisements can conflict with one another right -- the right of free speech of the advertiser. And yet this does not seem to be true. 


\section{Methods}

The paper sought to examine the coverage of the Seoul Secret case in Thai media in order to analyze the discourse around it. For the study a sample of 18 English language and 52 Thai language publications were collected. The sample included both print and online publications and social media posts that mentioned the story. The purpose was to identify the percentage of texts that bring to light the notion of the freedom of speech or a reference to the words and deeds dichotomy before making a plea for legal action.

\section{Results}

Analysis of the 18 English language and 52 Thai language publications indicated that $0 \%$ of all the texts in the sample included any argument for freedom of speech or distinguished between words and deeds. Thus, the value of free speech seems to be completely absent from the discourse about discriminatory advertising in Thailand. The concept of a liberal tradition was not a part of the discourse in the texts analyzed. This finding indicates the need for further examination of the issue.

In the classical liberal philosophical tradition, people should be free to do whatever they please as long as they don't violate the space of other people by invasion. As such, this view must be sharply distinguished from moral judgements. This is important, because claiming that a person should not be imprisoned or legally penalized for an action and claiming that this action is immoral are two very different things. This modern view is embodied in the views on human rights, which plea for making any discriminatory statements not only immoral, but also illegal. Those who promote laws that forbid discriminatory advertising insist on a legal penalty-a fine, and even a jail sentence to back up the prohibition.

Such an attitude is a relatively new approach. At one time in our recent history, the term "discriminating" had a positive value. It was a compliment. To say that a person was discriminating was to say that he was able to make fine distinctions (Block, 2010, p 118). And there was no unanimity of opinion on the issue of whether discriminatory advertising should be a legal offence. And John Stuart Mill's "On Liberty" should give us pause before closing our minds to alternative perspectives. In classical liberalism, free-speech rights are interpreted as but an aspect of the more basic rights to private property. The idea that that is not the business of law to make people moral is very old. Simple logic will lead anyone with a basic understanding of human nature to realise that a society in which everyone is always nice to one another is impossible.

\section{Discussion}

Perhaps the argument for banning pro-colorizing is so compelling that contrary positions are untenable. Is it indeed that straightforward and there is a solid justification for the ban of advertising that some people can find racially discriminating? Should Thailand indeed 
consider adopting such legislation? Since any coercion needs to be justified, it is important to understand the possible justifications behind the laws that would prohibit the discriminatory advertising, and thus make it morally permissible to punish the violators of these laws.

If the media sphere analysis reflects the existing spectrum of opinions, then there is no one in Thailand who opposes the idea of legal prosecution for discriminatory advertising. Unfortunately the texts in the sample did not seem to give a clear explanation of the purposes of the proposal. However, the texts mentioned some vague concerns that can be formulated in the following manner:

1. Advertising of skin whitening products causes insult and distress on people with darker skin tones;

2. Statements claiming that lighter skin tone is more preferable than dark skin tone is discriminatory in nature;

On the pages below we will analyze whether these concerns raised in the texts can represent a convincing attempt to justify coercion implied by the legislation against discriminatory advertising.

1. Should insult and possible distress caused by advertising constitute a criminal offence?

2. Does The White skin superiority claim constitute discrimination?

\section{Discriminatory Advertising as an Insult}

The idea that the laws against discriminatory advertising protect "feelings from injury" needs further examination. There is a confusing overlap and imprecision in definition which makes it a dangerous area for freedom of expression. "The giving of offence is arguably more a matter of the taking of offence by sensitive people". (Sturges, 2006). Certainly an affront may be felt by anyone encountering some form of unpleasant comparison. But it is impossible to understand how an affront of dignity can be a justification for the restriction of the freedom of expression.

Most people agree that experiencing a negative feeling (for example, becoming nervous or upset) is not itself a harm. There is no demonstrable or measurable lesion, damage, structural impairment, or loss of value, only a subjective state of mind with no obvious causal connections to any particular type of action or event (van Dun 2004, p. 38).

Is it ever justifiable to punish by the application of force someone's nonaggressive actions? Protecting people from discriminatory advertising is rather over-inclusive compared to a justifiable use of force in response to force (self-defense). If all "disrespectful comments" were to be banned because some people might find it offensive or depressing, why not forbid advertisements that promote teeth-whitening, weight-loss ornate ageing face 
creams, for not one of them shows any deference. People with wrinkles might find the ads that promote the cult of younger looking skin as discriminatory too!

The whole approach of protecting people from mere insult somehow implies that they have the rights to feel good about themselves, and in order to do so they have the right to control the opinions that other people may hold about them. They somehow acquire the right to dictate what others are allowed to think and speak of them and their looks. But every thought and every opinion that any person holds about anything or anyone belongs only to the person in question. Everyone has a right to the ideas or opinions in their own heads; and a right to and disseminate them -- this is exactly what we call freedom of speech.

An opinion about someone is neither a physical entity nor is it something contained within or on a person. It is purely a function of the subjective attitudes about a person contained in the minds of other people. But since these are ideas and thoughts in the minds of others, no one can in no way legitimately control them. No one can possibly any right to the ideas and minds of other people.

In fact, of course, people's subjective attitudes and ideas about everything will fluctuate continually, and hence it is impossible to stabilize attitudes by coercion; certainly it would be immoral and aggressive against other people's rights to try. Moreover, the views on skin tone are highly subjective and do differ from country to country and from culture to culture. Skin-whitening creams are popular in Asia and Africa, whereas in the West and Australia people buy self-tanning lotions. But even in Asian countries skin tones have with different social connotations. In the Philippines, once colonized by Spain, whiter skin is associated with being "mestizo," or of mixed ancestry.

What are the free-speech implications of our analysis? Statements specifically discriminating against particular groups of people have a long pedigree in the civil liberties debate. They have been characterized as "hate literature." They are displeasing, even malevolent. But banning them is a clear violation of free speech rights. Surely, any philosophy which takes seriously our rights of free expression would be exceedingly uncomfortable with a juridical proscription of "racist" statements (Block 2004).

This concept explains why justice cannot be achieved by trying to protect feelings. If the right is something that can be legitimately protected and enforced, then the right to feel good about oneself would include the right to use aggression in order to protect this right. This contradicts the principle of justice, as the punishment for hurt feelings (a non-violent crime) would include physical aggression.

Even if these advertisers make a claim that whiter skin is somehow superior and is associated with higher chances of success in life, it does not mean that they are discriminating - the rights of people with dark skin are in no way violated, unless being free of criticism is a legal right. 


\section{The White Skin Superiority Claim}

Despite flare-ups of controversy about the way skin lightening products are advertised, the products themselves are generally not controversial in Asia. Comments about the shade of a person's skin have been commonplace in a country with an abundance of skinwhitening products.

Skin whitening advertisement focuses not on race, but on skin tone, because white skin is the ideal of beauty in Asia. Advertisements that promote skin whitening products aim to motivate people to purchase products that will help them to replace a condition that they find less satisfactory (darker skin tone) with a condition that they find more satisfactory (fair skin tone). To motivate, they use different techniques that some people might find unpleasant or even unethical. But is there a crime? Does it constitute discrimination?

We need to examine the claim that these advertisements are indeed discriminatory in a broader context. How different are the advertisements that promote skin whitening from those that promote teeth whitening? Teeth whitening solutions manufacturers also make a point that white smile can bring success in business and personal relationship. "White smile opens all doors", they say. But does not this discriminate against people with yellow teeth? If no, why?

Products that help to combat puberty acne also promote the idea that a skin without acne is superior to a skin with acne. Is it discriminating too? If no, then why are skin cleansing products like Clearasil that promise a solution for acne different from skin whitening products? What about slimming programs and fitness club memberships? They promote the idea that a fit body is more preferable and beautiful than an overweight body. Is it discriminating too and thus must be outlawed? In all these examples manufacturers offer something that people consider beautiful - white skin, acne-free face, slim body. Why some of these are acceptable and another one is discriminating? It is not a rhetoric question, since the proponents of legal measures basically insist that promoting teeth-whitening solutions should be perfectly acceptable, while promoting skin-whitening product should be considered a criminal offence. The logic here is murky.

Why include only skin color in the list of criteria which should be banned from discriminatory advertising? Why not also include people with pimples, yellow teeth, extra weight and hair loss? As Block suggests $(2010,125)$, "one response to this reductio ad absurdum might be that the presently legally protected categories are justified in terms of one's ability to change. If a person cannot alter his condition, it becomes impermissible to discriminate against him; if he can, it is permissible".

However, this suggestion, as Block points out, would be difficult to agree with for a number of reasons. First, why is it morally relevant? Second, the advertising promises exactly this change - either in skin tone, or teeth shade, or hair loss. Third, if we include all these 
additional categories to the list of people against whom it would be illegal to discriminate, no one in our society will be able to interact with anyone on a truly voluntary basis. We can, of course, readily concede the gross immorality of making discriminatory statements about other people. But we must, nevertheless, maintain the legal right of anyone to do so (Rothbard 1998, pp. 125-127).

Discriminatory statements in advertising are defended, here, in the very limited sense that perpetrators should not be incarcerated, or otherwise interfered with by governmental authorities. It does not mean that such behavior is not odious, and morally repugnant in the extreme.

\section{Are Laws Against Discriminatory Ads Necessary?}

In three previous sections we demonstrated why laws that forbid discriminatory advertising cannot be justified. Legal measures that carry a threat of physical aggression attached to the prohibition can only be legitimately used against an actual or directly threatened violation of a person's human rights - and may not be used against any nonviolent "harm" that may befall a person's feelings. In this section we will show that not only these laws are not justifiable, but also they are unnecessary.

The point is that there are some other, extremely effective non-aggressive and non-legal means to deal with advertisers whose policies can be condemned and immoral. Those who for whatever reason do not like the advertisement can boycott the sales of goods from the company. They can run public campaigns, publish articles online and offline, make speeches - calling on everyone to boycott the company and also pressuring the company in a non-invasive manner to take down the controversial advertisement. Organizing such a campaign is also perfectly legal and within their rights of free speech.

"A boycott is an attempt to persuade other people to have nothing to do with some particular person or firm - either socially or in agreeing not to purchase the firm's product. Morally a boycott may be used for absurd, reprehensible, laudatory, or neutral goals".(see Rothbard 1998, 117).

From our point of view, the important thing about the boycott is that it is purely voluntary, an act of attempted persuasion, and therefore that it is a perfectly legal and licit instrument of action. Such an act is still a perfectly legitimate exercise of free speech and property rights. Whether we wish any particular boycott well or ill depends on our moral values and on our attitudes toward the concrete goal or activity. But a boycott is legitimate per se. If we feel a given boycott to be morally reprehensible, then it is within the rights of those who feel this way to organize a counter- boycott to persuade the consumers otherwise, or to boycott the boycotters. All this is part of the process of dissemination of information and opinion within the 'framework of the rights of private property. 
Campaigning against advertisers who are considered unethical can be viewed as a device which can be used by people who wish to take action against those who engage in activities which we consider licit but which they consider immoral. Thus, while discriminatory advertising should not be considered illegal, so would it be the right of those who find such activities morally repugnant to organize public campaigns against those who perform such activities. The point is that legal coercion is not the only action that can be taken against those some consider to be imoral advertisers; there are also such voluntary and persuasive actions as the boycott.

The shoppers could easily focus their dissatisfaction on the businessmen they consider responsible for discriminatory advertising. Protestors could, after all, merely take their business to other skin care manufacturers.

Do such campaigns work? They appear to. It is no contradiction to oppose the laws against discriminatory advertising, while at the same time declaring that such behavior is immoral and deserves sincere disapproval. And this is exactly what seems to happen today -people accused of discrimination can be charged with prejudice. In the US, skin whitening is discouraged by shaming in the media. There are no laws against it.

In Thailand and other parts of Asia, fairer skin is seen as socially desirable and there is big business in skin-whitening products. However, the Seoul Secret advert has provoked accusations of racism from locals. The advert stirred up a storm of debate online, with many Twitter users critical of the advert itself as well as the decision to withdraw it. One person wrote on a Thai-language forum Pantip.com: "I'm perfectly fine being dark-skinned and now you're saying l've lost? Hello? What?". "Suggesting people with dark skin are losers is definitely racist," wrote another. (BBC News 2016)

The ad for skin-lightening pills equates "whiteness" with success and "blackness" with failure, and has been withdrawn following a public outcry. The advert stirred up a storm of debate online, with many Twitter users critical of the advert itself as well as the decision to withdraw it. One person wrote on a Thai-language forum Pantip.com: "I'm perfectly fine being dark-skinned and now you're saying l've lost? Hello? What?" "Suggesting people with dark skin are losers is definitely racist," wrote another.

Seoul Secret has removed the 50-second advert after the social media backlash and issued an apology on its Facebook page. The apology stated the ad did not have the "intention to convey discriminatory or racist messages". Seoul Secret added: "What we intended to convey was that self-improvement in terms of personality, appearance, skills, and professionalism is crucial.

"However, we would like to express a heartfelt apology and thank you all for the comments. Currently, we have removed the video clip, related advertisements, and other planned materials to show our responsibility in this incident." 


\section{Conclusion}

The concept of freedom of speech is notably absent from the public discourse about skin whitening advertising. Companies are not only accused of racism and discrimination, but also there are voices that demand legal measures. People today cannot tolerate, insults, or views opposite to their own.

The desire to protect any feelings provokes, among other things, an illegitimate attempt to restrict freedom of speech. The need to protect the feelings of people does not seem to be a solid justification for making new laws that would prohibit discriminatory advertising. We may also conclude that laws against such statements in advertising cannot be justified by the attempt to combat incitement to hatred. What more, such laws are also unnecessary, because mechanisms of consumer choices along with reputation mechanisms provide an efficient solution.

\section{References}

Banton, Michael P. (1967). Race Relations, London: Tavistock.

BBC News (2016). 'Racist' Thailand skin-whitening advert is withdrawn, 8 January, BBC News, http://www.bbc.com/news/world-asia-35261748?ocid=socialflow_twitter

Block, W. (2004). Reply to 'Against Libertarian Legalism' by Frank van Dun, Journal of Libertarian Studies, Volume 18, no. 2, 1-30.

Block, W. (2010). The Case for Discrimination. Ludwig von Mises Institute: Auburn, Alabama.

Donald, A. (2014). Forget 'Real Beauty': Ads for Skin-Whitening Beauty Products Just Won't Die. AdvertisingAge, (September 02), http://adage.com/article/global-news/awful-ads-skin-whiteningproducts-die/294766/

Draper J., Kamnuansilpa, P. (2016). Lawmakers must heed the UN's International Convention on the Elimination of All Forms of Racial Discrimination. The Nation, (13 January), http://www.nationmultimedia.com/opinion/Skin-whitening-ads-are-blackening-Thailands-image30276724.html

Dubai (2008). Arab women use 'bottled racism' for whiter skin, AFP/LARABIYA.NET, 20 August.AFP/ALARABIYA. http://www.alarabiya.net/articles/2008/08/20/55137.html

Goffman, E. (1967). Interaction Ritual: Essays on Face-to-Face Behavior, New York, Pantheon Books.

Goffman, E.(1979). Gender Advertisement, Cambridge, MA: Harvard University Press.

Hall, R. E. (1995). The Bleaching Syndrome: African Americans' Response to Cultural Domination Vis-à-vis Skin Color, Journal of Black Studies, 26 (2), 172-84.

Hodal, K. (2013). Thailand racism row reignited by Unilever ad for skin-whitening cream. The Guardian, (27 October), http://www.theguardian.com/world/2013/oct/27/thailand-racism-unilever-skin-whiteningcream-citra

Hunter, J. E., \& Schmidt, F. L. (2004). Methods of Meta-Analysis: Correcting Error and Bias in Research 
Findings (2nd ed.). Thousand Oaks, CA: Sage. https://doi.org/10.4135/9781412985031

Hunter, M. L. (2010). Buying Racial Capital: Skin-Bleaching and Cosmetic Surgery in a Globalized World. The Journal of Pan African Studies, vol. 4, no. 4, June, 142-164

Kazim, A. (2008). Skin-whitening cream commercials. Dawn, 30 April 2012. http://www.dawn.com/news/714484/skin-whitening-cream-commercials

Lipsitz, G. (1998). The Possessive Investment in Whiteness: How White People Profit from Racial Politics, Philadelphia: Temple University Press.

Prachai Editorial (2016). Darkies are Ugly. Prachai.English, (09 January), https://prachatai.org/english/node/5755

Rothbard, M. N. (1998). The Ethics of Liberty. New York: New York University Press.

Russell, J. G. (1996). Race and Reflexivity: The Black Other in Contemporary Japanese Mass Culture, in Contemporary Japan and Popular Culture, John Whittier Treat (ed.), Honolulu: University of Hawai'i Press, 17-40.

Russell, K., Midge W., \& Hall, R. E. (1992). The Color Complex: The Politics of Skin Color among African Americans, New York: Harcourt Brace Jovanovich.

Sturges, P. (2006). Limits to freedom of expression? Considerations arising from the Danish cartoons affair. IFLA Journal, October, Volume 32, No. 3, 181-188. https://doi.org/10.1177/0340035206070164

Thompson,C. J. \& Maura T. (2004). Marketing Mythology and Discourses of Power. Journal of Consumer Research, 31 (June), 162-80. https://doi.org/10.1086/383432

Van, dun F. (2004). Natural Law and the Jurisprudence of Freedom. Journal of Libertarian Studies., Volume 18 , no. 2, 31-54.

Zambia: Ban sale of skin-bleaching creams-PHPF (2010). Lusaka Times, (31 March), Retrieved from http://www.lusakatimes.com/2010/03/31/ban-sale-skinbleaching-creamsphpf/ 